Archaeological Journal

\title{
The Votive Tablets Of The "Scriba" Demetrius at York
}

\section{W. King M.A.}

To cite this article: C. W. King M.A. (1882) The Votive Tablets Of The "Scriba" Demetrius at York, Archaeological Journal, 39:1, 23-37, DOI: 10.1080/00665983.1882.10852020

To link to this article: http://dx.doi.org/10.1080/00665983.1882.10852020

Published online: 14 Jul 2014.

Submit your article to this journal $\longleftarrow$

Q View related articles $\sqsubset$ 


\section{THE VOTIVE TABLETS OF THE "SCRIBA" DEMETRIUS AT YORK.}

By C. W. KING, M.A.

It is so rare an event to meet with any names (other than Imperial) in our Roman-British inscriptions that survive, in the mention of them by contemporary writers, that even the possibility of any such identification, however open to cavil, is well deserving of being pointed out. And in the present case, should this indentification be allowed as well founded, some highly interesting points connected with the history of this country (now almost a blank for the same period) will be found indirectly illustrated by the same record. In the York Museum are preserved two very small bronze plates," cut into the shape of tabello scriptorice (the regular form of votive tablets), and bearing, in dotted letters, these inscriptions :-

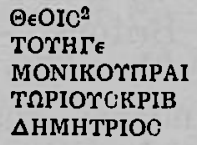

$\triangle$ HMHTPIOC

$\omega \mathrm{K} \in \mathrm{AN} \Omega \mathrm{I}$

RAITH@TI

$\triangle$ HMHTPI.

Such dotted inscriptions require a practised hand to produce them with evenness : that they were stamped by some person belonging to the Temple, where they were affixed to the walls, whose proper business it was to make them to order, is attested by their being found executed in precisely the same manner in every sanctuary that has been explored all over the ancient world, from the Temple of the Silurian "Nodens" at Lydney, to those of Olympia and Dodona.

1 Published in fac-simile in the "Philological Journal," vol, vii, pp. 126-129.

2 The semi-circular forms of $E$ and $\Sigma$ first appear on the coins of Polemo, King of Pontus, a nominee of M. Antony's; they became general in the time of Domitian, 
Who then was this "Scriba Demetrius" who thus testifies his gratitude to the god or goddess of the seas for his safe voyage; and secondly, to the deities in general, who protected the residence of the Roman Præfect? The inscriptions, of themselves, make three points certain in his history. $\mathrm{He}$ was a Greek; a government officer-Scriba, for which he could find no precise equivalent in his own language, but exactly answering to our "clerk," - and probably one employed in the finances, like the poet Horace, scriba qucestorius; and. lastly, he was a scholar, as he manifests by the care taken to add the iota subscriptum to the dative, a grammatical nicety, but little attended to by the inscription-makers of imperial times.

Now Plutarch, in the opening of his invaluable Treatise "On the Cessation of Oracles," mentions the visit to himself (then residing at Delphi) of two "holy" men, the one being Demetrius, the grammarian, just returned from Britain on his way home to Tarsus; the other, Cleombrotus, the Lacedemonian, who had been travelling long about Egypt and the coasts of the Red Sea.

Another point in the history of Demetrius, and one of vital importance to this inquiry, is mentioned farther on, ${ }^{2}$ where he says that "by the emperor's mandate" "he had crossed over to an island lying the nearest to the coast of several others, which was inhabited by a few religious men held in high veneration by the Britons"-probably Anglesey, that last retreat of the Druids. The emperor, unluckily for my object, is not named, that being unnecessary for the dialogue whilst he was still the reigning prince; but who is meant can be determined ${ }^{3}$ with tolerable exactness from allusions in the preceding chapter. Plutarch there calls a certain Emilian "aged;" and this Amilian's father had lived under Tiberias, who was emperor down to A.D. 37. It does not even appear

\footnotetext{
I iepol, probably meaning persons who had been initiated, for he couples such men with the priests of the oricle in two places further on.

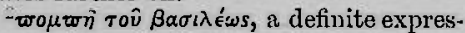
sion, only applicable to one in the imperial service. C'ap. xviii.

${ }^{3}$ Plutarch, too, was: an old man when he wrote this dialogue, for he uses the expression "in spite of my years," in
}

Cap. xlvii. $\mathrm{He}$ was still living under Trajan, his former pupil; his letter to him on his accession to the empire is extint in Suidas. A still closer approximation to a date is found in the 'De Pytlix Oraculis,' Cap. ix, in the - allusion to "the quite recent and novel clisasters at Cumoc and Dicæearchia," from the great eruption of Vesuvius $A, D, 79$. 
that the son was living when Plutarch wrote; for his friends speak of having heard a certain wondrous tale from the aged Amilian, as if his telling it also was a thing of the distant past. This calculation easily brings the residence of Demetrius in Britain within the reign of Domitian, by which time the pacification of the whole island had been completed by Agricola. As this general laboured sedulously to promote the civilisation of the new subjects of Rome; and, as Tacitus records, ${ }^{1}$ paid particular attention to instructing them in letters, as well as in the useful arts. This grammaticus (a term exactly corresponding to "schoolmaster") may have come over originally in connection with the latter purpose. Another indication of this date is supplied by the fact that Britain must have been completely reduced under Roman rule, when he visited the Holy Isle, for its distinction as "one of many others," only applies to those lying off the northwest coast from Anglesey upwards.

His remark that many of these isles, at that time a desert, were named after "dæmons" and heroes, is borne out by the "fable of Belerus old," which gives its classic name to the Land's End and the Scilly Isles.

Again, the circumstance that Demetrius made this visit of inspection " at the emperor's command," puts it out of doubt that he went in an official capacity, perhaps connected with the Treasury, or perhaps to investigate the source of the tin and of the gold, which for unknown ages had flowed out of Britain into Gaul. The emperor, whether Domitian or Trajan, was certainly too much a man of business to despatch a philosopher so far on a purely " scientific mission," to inquire into the supernatural phenomena so frequent there, the apparition of daemons and genei, the prison where lay old Saturn wrapped in enchanted slumbers, and other tales of wonder picked up by the religious Greek during his visit, and afterwards related to the great edification of the conclave at Delphi, who already knew, or did not care to know what would be of so much value to $u s$, what was the public business that carried him thither.

If Demetrius was actually holding office under the

1 "Jau vero principum filios liberal- norum studiis Gallorum anteferre." Cap. ibus artibus erudire, et ingenia Britanxxi. 
Imperial Government, there is no difficulty in understanding wherefore he should designate that office by its proper Latin name upon his tablet rather than by some Greek equivalents, which perhaps did not precisely express the every-day meaning of the title; and this consideration may have made him retain the name of "Scriba," by which he was entered upon the governmental books, and which to Grecize might be construed into a petty crimen lesce majestatis against the dignity of Rome. ${ }^{1}$

Lastly, the epithet "holy," given him by Plutarch (as already noticed), bears with great weight upon the subject before us.

The exact sense in which Plutarch uses it of Demetrius, he explains in the next passage with respect to his fellow-guest, Cleombrotus. The latter is described as a person of sufficient means, who passed his whole time in travelling about the world in the study of "Theology "a term far from bearing its present meaning of the laborious acquisition of a stock of arguments to be used in the defence of an established religious system, but rather the inquiry into the so-called "theosophy" of different nations, the insight into the hidden meaning of ceremonies to be gained by initiation into their several mysteries, and the speculations of the philosophers upon the nature of the Unseen World. What these inquiries really tended to may be gathered from the long report he gives the company of his conferences with an Indian hermit (whom he had taken vast trouble and been at great expense to discover) upon the nature of those beings that hold the middle place between gods and men : the Inspiration of Oracles : and the Plurality of Worlds-all this is given in detail, and with an air of truthfulness about it that almost makes us believe that we have here the sketch of some real system of Hindoo cosmogony, and not an imaginary interlude of Plutarch's own composition. Such being the character of his Demetrius, what could be better applied to the Demetrius of the York tablets, a man at once devout and learned, who leaves enduring testimony of thanksgiving to the

1 There is every renson to believe that he had, long [reviously, been in the service of the Governor of Cilicia, judging

from certain expressions in a curious story about the Oracle of Mopsus, to be related further on. 
primeval Hellenic deities (then almost forgotten by his unlearned contemporaries), for the protection vouchsafed upon his long voyage (perhaps upon his safe return from the Holy Isle); as well as to the Roman gods on account of some favour then and there conferred upon him, and which may very well have been the grant of the office giving him the title of "Treasury-Clerk." Eboracum was, from the first, the station of one of the three legions forming the garrison of Britain. $\mathrm{H}_{\gamma}^{\prime} \mu \omega \nu$ is the literal translation of Dux; but it is now impossible to decide whether the term was employed by Demetrius to designate the Tribune in command of the legion; or, in the wider sense, ${ }^{1}$ it takes in the later historians, where the title Dux stands for the military governor of any province, as prceses for the civil one. A man like Demetrius, with a hankering after strange, primæval, religious notions and practices, could not anywhere have found a more promising field for his researches than in the Britain of the first century. There was the last refuge of old Celtic doctrine, fast dying out in Gaul under the influence of Roman civilisation; in the same way as this island had been the fountain-head of those same doctrines-in modern phrases, the "Theological university" of all the Celts. "Disciplina in Britannia reperta atque inde in Galliam esse translata existimatur; et nunc qui eam rem diligentius cognoscere volunt plerumque illo discendi causa proficiscuntur" -is the express statement of Cosar. ${ }^{2}$ And what was the course of studies they pursued during their residence at the Druidical colleges? Cæsar tells us a little further on: "His excitati præmis, et sua sponte, multi in disciplinam conveniunt, et a parentibus propinquisque aluntur ....... In primis hoc volunt persuadere, non interire animas, sed ab aliis post mortem transire ad alios; atque hoc maxime excitari ad virtutem putant, metu mortis neglecto. Multa preterea de sideribus atque eorum motu, de mundi ac terrarum magnitudine, de rerum natura, de deorum immortalium vi ac potestate, juventuti tradunt." And fully a hundred years later Pliny found the same notions flourishing here

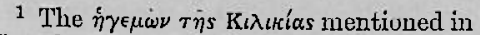
Cap.xly. is certainly the imperial governor

of that province.

2 De Bello Gallico; vi. 13.
} 
as vigorously as ever, though the privileges of the teachers had been sadly curtailed. "Gallias utique possidet [Magia ${ }^{\prime}$ et quidem ad nostram memoriam; namque Tiberii Cæsaris princepatus sustulit Druidas eorum, atque hoc genus vatum medicorumque Senatus Consulto. Quid ego haec commemorem in arte Oceanum quoque transgressa, atque ad Naturæ inane pervecta. Britannia hodieque eam attonite celebrat tantis ceremoniis ut dedisse Persis videri possit: adeo ista toto mundo consensere quamquam discordi et sibi ignoto. Nec satis æstimari potest quantum Romanis debeatur qui sustulere monstra in quibus hominem occidere religiosissimum erat, mandi vero etiam saluberrimum."

A few scraps of these speculations (far too wild to be the mere inventions of a Greek) are preserved to us in another very curious treatise of Plutarch's. ${ }^{3}$ One of the company relates a long story, received from a certain foreigner who, as he pretended, had once formed part of a deputation, sent every thirty years from some unnamed region of the West to a large continent lying at some distance off the British coast, ${ }^{4}$ for the purpose of performing religious duties during the same space of time. This consecrated land must have been the very place, the fame whereof had reached Demetrius upon his visit to the Holy Isle; for there stood the prison of Old Saturn, who in his enchanted slumber dreams of whatsoever his unnatural Son is about to do, and forthwith discloses the same to his attendant Genii, who in their turn impart the same foreknowledge to the pious hermits with whom they hold daily converse. Of these revelations of the returned servitor, the most remarkable, and, upon its internal evidence, the most genuine of these pieces of Celtic theosophy, is the theory of the composition and future state of the soul, and the nature of the beings that fill up the vast interval between God and Man.

"All that he had endured, and how many nations he had passed through, consulting their sacred books, and

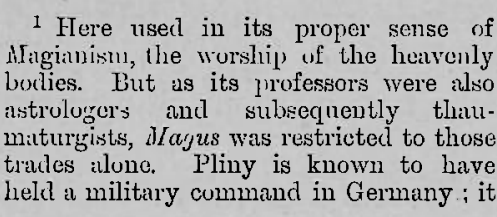

is not impossible that he had been in Britain also.

2 Nat. Hist., $\mathrm{xxx}, 4$.

3 "De Facie quee in orbe Luno apparet." Cap. xxvi., et seq.

4 "A five days' sail to the westwards" perhaps Ireland. 
getting himself initiated into all their mysteries, would take a whole day to recount in the way that he related it to us, describing all the circumstances well and minutely, but as much of them as is connected with the present inquiry, you shall now hear. For he spent a very long time at Carthage, ' because he received great honours from us for having discovered, deposited in the earth, some sacred parchments, which had been secretly carried off at the time when the former city was destroyed and which had been concealed for many years.

"Of the Visible Powers, he said, ought we (and also exhorted us) especially to worship the Moon, as being in reality, and likewise reputed, ${ }^{2}$ the 'Ruler of Life?' When I was astonished at this, and begged for some clearer explanation,- - many things, Sylla (said he) are told amongst the Greeks, but not all rightly concerning the gods. For instance at starting, you are right in calling the same personage 'Demeter' and the 'Maid,' but not right in supposing that the place of each is one and the same, and that they are occupied about the same things, for the one is upon Earth, and mistress of the things on Earth; the other in the Moon, and of things pertaining to the Moon. She is named 'The Maid' and 'Persephone,' the latter as being the 'Bringer of Light,' but 'Maid,' because we call maid (pupil) that part of the eye on which the image of the spectator is reflected, just as the image of the Sun is reflected in the Moon. In the legends told of their wanderings and going in search of each other, there is a certain portion of truth, for they long for each other while they are apart, and often embrace under the obscuration. ${ }^{3}$ Now the being at one time in power and in the light, at another time in darkness and in night, is not fabulous as far as regards the Maid, but the time has occasioned error in the reckoning, since it is not during six months, but at intervals of six months, that we see her enveloped in shadow by the Earth as if by a mother, but rarely experiencing this at intervals of five months. For it is impossible

\footnotetext{
I Sylla, the spenker, was an African.

2 Not by the Greeks, certainly. This must upply to the Celts.

${ }^{3}$ Of the Moon by Lurth's shadow during in eclipse.
} 
for her to leave the Shades, and for them to pass, as Homer disguising the thing hath not ill said :--

'Into Elysian plains, and Earth's recess.'

"For where the Earth's shadow ceases to reach this point, we suppose, the limit and end of Earth. To this place no wicked or unpurified person ascends ; but the good, after their decease, being carried thither continue there, enjoying a very tranquil life, though not a blissful one, nor that of gods, until the 'Second Death.' Man, most people rightly think, a composite being, but not rightly think to be composed of two things only-body and soul; for they reckon the mind as being only a part of the soul, being no less in error than those who think the soul only a part of the body, for the mind is as much better and more divine than the soul, as the soul is superior to the body. For the conjunction of body and soul produces Sensation, but that of mind and soul produces Reason; whereof the one is the origin of pleasure and pain, the other of vice and virtue. Of these three combined things, Earth furnishes for the birth the Body; the Moon the Soul; the Sun the Mind; just as he supplies light to the Moon.

"The death which we die makes the man two instead of three; the Second Death makes him one out of two. The First Death takes place in the region of Demeter, because Earth and the dead also are subjected to her; hence the Athenians used to call the dead 'Demetrians.' The Second Death takes place in the Moon, the region of Persephone. Of the former, the consort is the earthly Hermes; of the latter, the Heavenly. The former separates soul from body hastily and with violence; but Persephone gently and slowly loosens mind from soul ; and for this reason she has been named 'the Only-begotten," because the best part of a man becomes single when separated from the rest by her agency. Each of these changes takes place, according to Nature, as follows. Every soul, whether without mind or joined to mind, on departing from the body, is ordained to wander in the region between the Moon and Earth for a term, not equal in all cases; for the wicked and incontinent pay a penalty

1 To be unclerstood in an active sense, by a very forced interpretation. 
for their sins; whereas the virtuous, in order, as it were, to purify themselves and to recover breath; after the body, as being the source of sinful pollution, must pass a certain fixed time in the mildest (or pleasantest) region of air, which they call 'the Meadow of Hades.' There, as though resting in their native land after enforced banishment, they taste of joy such as the initiated into Mysteries feel ; mingled, however, with trouble and apprehension, joined to a peculiar hope, for she (the Moon) drives off and tosses away many of them while already making for the Moon; and also they behold the ghosts of the (wicked) persons there turned head over heels, and, as it were, tumbling down into the abyss below. But such as get firm footing there (on her surface), crowned with garlands, like victors in the games, entitled 'Crowns of Stedfastness, ${ }^{\text {'2 }}$ made out of feather's: because the irrational and passionate part of the soul they have, in life, given over to reason, well disciplined and kept under restraint. In the next place, their sight becomes like a sunbeam (in intensity), and the soul, wafted on high by the air surrounding the moon, gains tone and vigour from the same, (just as hero below tools, being steeled, acquire it from the tempering) because that which was unsubstantial and diffused becomes solid and transparent, so as to be nourished by the exhalations it meets with there; and Heraclitus hath well said 'that souls in Hades have the sense of smell.' They contemplate, in the first place, the magnificence and beauty of the Moon, and her nature too, which is not simple and unmixed, but as it were, a combination of Star and Earth; for just as Earth, mixed with Air and Water becomes soft; and the blood mingling itself with. the flesh, produces sensibility; in like manner they say that the Moon, being made up of starry and earthy matter from her inmost depths, becomes both animated and generated, and at the same time gains the symmetrical arrangement of its levity (lighter particles) around the centre of its mass, for a counterbalancing force to her own gravity. For it is in this way that our world, being made up out of elements that by their own nature tend, some upwards, some downwards, is

${ }^{1}$ In the Middle Space, undergoing purgation of their sins. ${ }^{3}$ Ev̀ $\sigma r a \theta \epsilon^{\prime} \alpha s$. 
preserved from all motion in its place. . . . . . The breadth and magnitude of the Moon is not what geometricians pretend, but much greater; for she measures the shadow of Earth (in eclipses) a few times only with her own magnitude (diameter), not in consequence of its smallness, but because she puts forth all her speed that she may pass through the darkened space, and carry away with her the souls of the good who are eager for it and cry aloud to her (to hasten her course) because they no longer hear, whilst immersed in Earth's shadow, the harmony of the heavens, ${ }^{1}$ and, at the same time, the souls of such as are suffering punishment (in the middle space) rush up towards her from below, through the shadow, wailing and shouting (for which reason, during eclipses, most people clatter their brass pots, clap their hands, and make noises in order to scare away the ghosts), for the so-called Face frightens them when they come nigh, looking grim and horrible. Such is it not in reality, but like as Earth has deep and great gulfs, the one flowing in towards us through the Pillars of Hercules, others flowing outwards as the Caspian and those in the Red Sea; in like manner there are deep places and gulf-like cavities in the Moon, whereof the largest is called 'Hecate's Dungeon,' in which the souls either suffer or inflict punishment for the the things that they have either done or endured, after they have been already made Genii." As for the two smaller cavities, because the souls pass through them on their way to Heaven, or towards Earth on their return thither: the one is denominated 'The Elysian Plain,' the other 'The Passage of Persephone the Terrestrial.' The Genii do not always pass their time upon the Moon, but come down hither and take charge of Oracles; they are present and assist at the most advanced of the initiatory rites in the sacred Mysteries; they act as punishers and guards upon evildoers; they shine as saviours in battle and at sea $;^{3}$ and whatsoever things they do amiss in these capacities, either out of spite, unfair partiality, or envy, they are punished for it, for they are driven down again to earth and imprisoned in human

2 "Music of the Spheres."

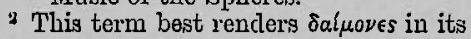

proper acceptation.

3 "Fratres Helenx, lucida sidera." 
bodies. Amongst the best of these Genii (they told him) were those who wait upon Saturn novv, and the same in the olden time were the Idæo Dactyli in Crete, the Curetes in Phrygia, the Trophonii in Bootia at Lebadea, and others without number in different parts of the world, of whom the holy places, honours and titles yet remain, although the powers of some have ceased to exist, since they have suffered a removal of their virtue to another place. This change they ${ }^{2}$ experience, some sooner, others later, when the Mind has been separated from the Soul. The Mind separates itself through a a desire of reaching the 'Image' in the Sun, through which shines forth the Desirable, the Beautiful, the Divine, the Blissful-to which every unmixed (unalloyed) nature aspires in different ways. For the Moon herself, out of desire for the Sun, revolves round, and comes into conjunction with him, because she longs to derive from him the generative principle.

"The nature of the Soul is left behind in the Moon, retaining vestiges, as it were, and dreams of life ; and, on this account, you must hold it to be said rightly- 'Like to a dream the soul took wing and fled.' For the soul does not suffer this change all at once as soon as separated from the body; but afterwards, when it is become desolate and solitary, when the Mind is departed....... For each individnal of us is not Anger, nor Fear, nor Desire, - just as he is not mere pieces of flesh or humours -but that wherewith we think and understand is the Soul, impressed by the Mind, and in its turn impressing the body and impinging upon it from all parts, it models the form of the Soul, so that although the latter may continue a long time separated from both (this Mind and Body), yet, as it retains their form and imprint, it is appropriately denominated 'Spectre' ( $\left.\varepsilon^{\prime} \delta \omega \lambda o \nu\right)$. Of these spectres the Moon is the element, for they are resolved into her substance like as the bodies of the dead are into Earth's. Quickly resolved are the temperate, such as have lived a tranquil philosophical and leisurely life here on earth, for being cast adrift by the mind, and no longer subject to the passions, they wither and waste away. Of those that were ambitious, busy, amorous, or irascible when in the

1 The people of the Holy Isle.

2 The Genii presiding over such oracles.

voL, $\mathrm{xxxix}$. 
body, the souls are haunted, as by dreams, with memories of their past life, and are troubled by the same, like those (dreams) of Endymion of old. Eor their restless and passionate temperament stirs them up, and urges them away from the Moon towards a second birth. She, however, suffers them not to escape, but recalls them to herself, and soothes them to remain with her. For it is far from a quiet or orderly state of things when souls separated from Mind get possession of a body that is subject to passion. Of such souls came, perchance, the Tityi and the Typhones of old; and that 'Typhon'" who used to interfere with the oracular power at Delphi ; for they are destitute of Reason, actuated by the passionate part of their nature, and puffed up with pride and self-conceit. Yet in time, even these the Moon absorbs into herself, and reduces to order. In the next place, the sun having impregnated the Mind with vital force, produces new souls ; and, thirdly, Earth furnishes a body, for she takes after death as much as she gave at birth $;^{2}$ whereas the Sun receives nothing, but only takes back the Mind, which he gave at first; but the Moon both gives and takes, and puts together and separates, in virtue of two different powers belonging to her; of which the combining power is called 'Ilithyia,' the separating one, 'Artemis.' And of the Three Fates-Atropos, seated in the Sun, supplies the origin of birth; Clotho, moving around the Moon, unites and mixes together the several parts; lastly, Lachesis, upon Earth, who has the most to do with Fortune, puts her hand to the work. For the inanimate part of Man is powerless, and liable to be acted upon by other things, but the Mind is impassive and independent, and the soul of a mixed nature, intermediate between the two, just as the Moon hath been made by the Deity, a mixture of things above, and of things below; ' a great full horn,' bearing the same relation to the Sun that the Earth bears to the Moon. "All this, said Sylla, I heard the stranger recounting, the chamberlains and ministers of Saturn had (said he)

\footnotetext{
1 Error for "Python," from whence Apollo delivered Delphi.
}

"He has previously said "Earth furnishes a body for the births." 
related it to him. You, Lamprias, are at liberty to make what use you please of the story." "

If the Druids really carried their pupils into such transcendental spectlations as these " upon the heavenly bodies and their motions; upon the magnitude of the universe and the Earth; upon Nature in general ; upon the essence and power of the immortal gods" (to use Cesar's words), then in good sooth, our Demetrius was rewarded for his pains in visiting their distant retreat by hearing of "many things in heaven and earth not dreamt of in his philosophy."

I have, above, slightly alluded to a casual expression of Plutarch's that gives reason to suppose that his Demetrius was employed by the Roman Government, in some capacity or other, previous to his visit to this island. The passage is very curious in itself, and as Plutarch is a "lost classic" to Grecists of the modern type, I shall be doing them a service by transcribing it at length. ${ }^{2}$

Then Demetrius.- "I know not the present state of things (in Cilicia), for, as you are aware, I lave now been away from home for a very long time. But when I was there, the Oracle of Mopsus still flourished as well as that of Amphiaraus. But I have a very wonderful event to tell, which happened during my visit to the Oracle of Mopsus. The governor of Cilicia being sceptical in religious matters-disbelieving them, I fancy, out of wantonness-for he was an extremely insolent, wicked man, and had about him a set of Epicureans, who, after their fine fashion and 'Natural Science' principles, made sport of all things of the kind, as they themselves often boasted, he despatched his freedman, furnishing him, like a spy going into the enemy's camp, with a letter in which the inquiry was written, nobody knowing the contents. The fellow, therefore, having passed the night, as is the rule, within the sanctuary, and having slept there, related to us next morning the following dream: He dreamed that a man of handsome appearance stood over him and shouted 'A black one,' and nothing more ; but forthwith vanished. This seemed to us absurd, and

\footnotetext{
1 "So treat the story as you please, to = "De defect. Orac." Cap. xlv. believe it or not."
} 
caused us great perplexity ; the governor, however, was astonished at it, and making a gesture of adoration and opening the letter, showed us therein written the question-' Whether shall I sacrifice to Thee a white or a llack bull?' So the Epicureans were put to the route, and he himself offered the sacrifice, and ever afterwards held Mopsus in respect."

As this governor of Cilicia is not named, it may be inferred he was still living; and Demetrius, after his . disrespectful remarks upon his character, might think it discreet to omit his name; and thus we lose another definite indication of date. But the use of the pronouns "us" and "we" proves pretty clearly that Demetrius was in his service at the time, for the nature of circumstances would make us believe that the response of Mopsus would be communicated to the governor in private, his immediate dependents and officers alone being present to be puzzled at the tale brought back by the messenger, and to be allowed the privilege of reading the experimental letter.'

I must not, however, pass over an objection against my thesis which will doubtless occur to critical readers, that "Demetrius" was, next to "Apollonius," the commonest of Greek names in Roman times, and that consequently the identity of names in the two cases is of no value whatsoever. The only reply to this (of small force, it must be confessed) is that inscriptions in Greek are so rarely discovered in Britain that no other examples are known besides two small altars from Hadrian's Wall, and as these are of white marble it is more probable they were imported ready engraved than that they were sculptured in this country. This fact leaves to my argument the weight to be derived from the taking into the account the natural proclivities of a grammarian by profession, from whom something pedantic and not of everyday use was to be expected. Another objection, that the SCRIB is only the abbreviation of the patrician nomen "Scribonius," assumed, according to rule, by some freed man of the family-is obviated by our finding SCRIBON upon the coinage of that gens as the only allowable contraction of

1 Harrison, an Elizabethan writer, in his "Description of England," says that the tract "De Mir'abilibus Britannice" was ascribed to this Demetrius. It is now given to Nennius; and, upon its own evidence, has no clain to an antique origin. 
the word. And further, that his profession precedes his name in the case of our Demetrius is made a matter of certainty by the well-known Pompeian inscription in which (and nearly at the same date) SCRIBA ISSVS solicits the patronage of Cerrinius Votia, ædile of that city.

The whole matter is a question of probabilities, strict proof being impossible for want of sufficient data; my sole grounds for identification are the names of the two persons, their personal characters, their employment under the same government, and the coincidence of the time of their visit to Britain. I know not of what weight others will find these considerations; to myself they almost bring conviction, perhaps, because

$$
\text { "In quod volumus credula turba sumus," }
$$

and the satisfaction in discovering so curious and unusual an historical record is an irresistible temptation to magnify mere trifles, favourable to one's cause, and to tempt the mind to soar above the regions of dull fact upon the wings of fancy. 